Townsend, and several brought to London by the medical officer who accompanied Captain BACK in his late Arctic journey. Among the individuals which I have examined I have found considerable differences as to size and markings, which may be attributed to age and sex. My drawing was taken from a remarkably fine specimen in the collection of the Zoological Society of London.

The comparatively small size of this bird's eyes renders it probable that it hunts by day, and the remarkable smallness of its feet and claws induces me to think that it does not prey on large animals. Dr. RICHARDson says that "it is by no means a rare bird in the Fur Countries, being an inhabitant of all the woody districts lying between Lake Superior and latitudes $67^{\circ}$ or $68^{\circ}$, and between Hudson's Bay and the Pacific. It is common on the borders of Great Bear Lake; and there, and in the higher parallels of latitude, it must pursue its prey, during the summer months, by day-light. It keeps however within the woods, and does not frequent the barren grounds, like the Snowy Owl, nor is it so often met with in broad day light as the Hawk 0 wl, but hunts principally when the sun is low; indeed, it is only at such times, when the recesses of the woods are deeply shadowed, that the American hare and the murine animals, on which the Cinereous Owl chiefly preys, come forth to feed. On the $23 \mathrm{~d}$ of May I discovered a nest of this Owl, built on the top of a lofty balsam poplar, of sticks, and lined with feathers. It contained three young, which were covered with a whitish down. We got them by felling the tree, which was remarkably thick; and whilst this operation was going on, the two parent birds flew in circles round the objects of their cares, keeping, however, so high in the air as to be out of gunshot; they did not appear to be dazzled by the light. The young ones were kept alive for two months, when they made their escape. They had the habit, common also to other Owls, of throwing themselves back, and making a loud snapping noise with their bills, when any one entered the room in which they were kept."

Great Grey or Cinereous Owl, Strix cinerea, Nutt. Man., vol. i. p. 128.

Cinereous Owl, Strix cinerea, Swains. and Rich. F. Bor. Amer., vol, ii. p. 77.

Great Cinereous Owl, Strix cinerea, Aud. Orn. Biog., vol. iv. p. 364.

Upper parts greyish-brown, variegated with greyish-white in irregular undulated markings; the feathers on the upper part of the head with two transverse white spots on each web; the smaller wing-coverts of a darker brown, and less mottled than the back; the outer scapulars with more white on their outer webs; primaries blackish-brown toward the end, in the rest of their extent marked with a few broad light-grey oblique bands, dotted and 
undulated with darker; tail similarly barred; ruff-feathers white toward the end, dark brown in the centre; disks on their inner sides grey, with black tips, in the rest of their extent greyish-white, with six bars of blackish-brown very regularly disposed in a concentric manner; lower parts greyish-brown, variegated with greyish and yellowish-white; feet barred with the same.

Female, $30 \frac{1}{2}, 48 \frac{1}{2}$.

\title{
THE BAR RED OWL。
}

\author{
+Syrnium nebulosum, Linn.
}

\section{PLATE XXXVI.-MALE.}

Should you, kind reader, visit the noble forests of the lower parts of the State of Louisiana, about the middle of October, when nature, on the eve of preparing for approaching night, permits useful dews to fall and rest on every plant, with the view of reviving its leaves, its fruits, or its lingering blossoms ere the return of morn; when every night-insect rises on buzzing wings from the ground, and the fire-fly, amidst thousands of other species, appears as if purposely to guide their motions through the sombre atmosphere; when numerous reptiles and quadrupeds commence their nocturnal prowlings, and the fair moon, empress of the night, rises peacefully on the distant horizon, shooting her silvery rays over the heavens and the earth, moving slowly and majestically along; when the husbandman, just returned to his home, after the labours of the day, is receiving the cheering gratulations of his family, and the wholesome repast is about to be spread out;-it is at this moment, kind reader, that your ear would suddenly be struck by the discordant screams of the Barred Owl. Its whah, whah, whah, whah-aa is uttered loudly, and in so strange and ludicrous a manner, that I should not be surprised were you to compare these sounds to the affected bursts of laughter which you may have heard from some of the fashionable members of our own species.

How often, when snugly settled under the boughs of my temporary encampment, and preparing to roast a venison steak or the body of a squirrel, have I been saluted with the exulting bursts of this nightly disturber of the peace, that, had it not been for him, would have prevailed around me, as well as in my lonely retreat! How often have I seen this nocturnal marauder alight within a few yards of me, expose his whole body to the glare of my fire, and eye me in such a curious manner that, had it been 



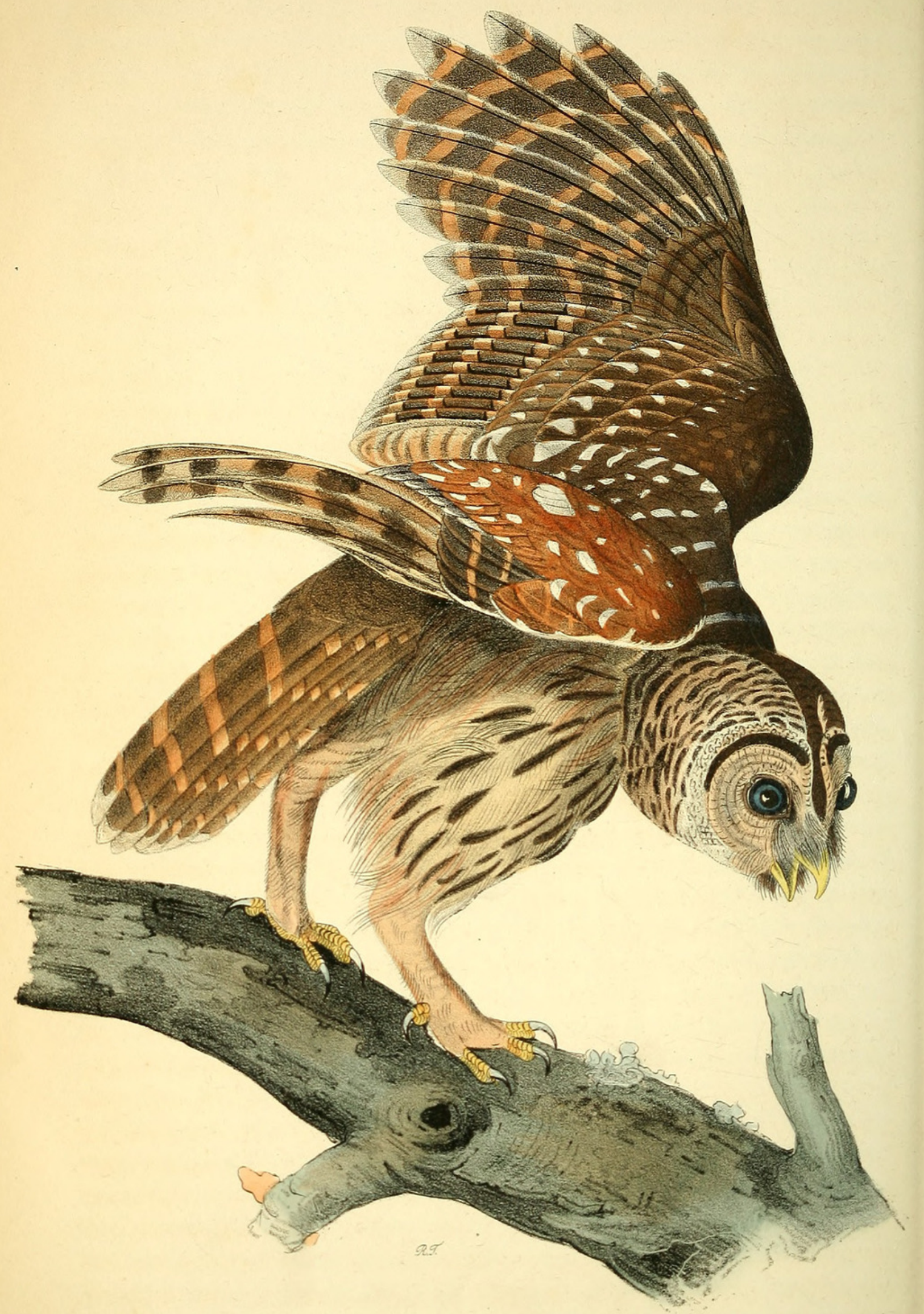


reasonable to do so, I would gladly have invited him to walk in and join me in my repast, that I might have enjoyed the pleasure of forming a better acquaintance with him. The liveliness of his motions, joined to their oddness, have often made me think that his society would be at least as agreeable as that of many of the buffoons we meet with in the world.

Such persons as conclude, when looking upon Owls in the glare of day, that they are, as they then appear, extremely dull, are greatly mistaken.

The Barred Owl is found in all those parts of the United States which I have visited, and is a constant resident. In Louisiana it seems to be more abundant than in any other state. It is almost impossible to travel eight or ten miles in any of the retired woods there, without seeing several of them even in broad day; and, at the approach of night, their cries are heard proceeding from every part of the forest around the plantations. Should the weather be lowering, and indicative of the approach of rain, their cries are so multiplied during the day, and especially in the evening, and they respond to each other in tones so strange, that one might imagine some extraordinary fête about to take place among them. On approaching one of them, its gesticulations are seen to be of a very extraordinary nature. The position of the bird, which is generally erect, is immediately changed. It lowers its head and inclines its body, to watch the motions of the person beneath, throws forward the lateral feathers of its head, which thus has the appearance of being surrounded by a broad ruff, looks towards him as if half blind, and moves its head to and fro in so extraordinary a manner, as almost to induce a person to fancy that part dislocated from the body. It follows all the motions of the intruder with its eyes; and should it suspect any treacherous intentions, flies off to a short distance, alighting with its back to the person, and immediately turning about with a single jump, to recommence its scrutiny. In this manner, the Barred Owl may be followed to a considerable distance, if not shot at, for to halloo after it does not seem to frighten it much. But if shot at and missed, it removes to a considerable distance, after which its whah-whah-whah is uttered with considerable pomposity. This $\mathrm{Owl}$ will answer the imitation of its own sounds, and is frequently decoyed by this means.

The flight of these Owls is smooth, light, noiseless, and capable of being greatly protracted. Once, whilst descending the Ohio, not far from the well-known Cave-in-rock, about two hours before sunset, in the month of November, I saw a Barred Owl teased by several crows, and chased from the tree in which it was. On leaving the tree, it gradually rose in the air, in the manner of a Hawk, and at length attained so great a height that our party lost sight of it. It acted, I thought, as if it had lost itself, now and then describing small circles, and flapping its wings quickly, then flying in VoL. I. 
zig-zag lines. This being so uncommon an occurrence, I noted it down at the time. I felt anxious to see the bird return towards the earth, but it did not make its appearance again. So very lightly do they fly, that I have frequently discovered one passing over me, and only a few yards distant, by first seeing its shadow on the ground, during clear moon-light nights, when not the faintest rustling of its wings could be heard.

Their power of sight during the day seems to be rather of an equivocal character, as I once saw one alight on the back of a cow, which it left so suddenly afterwards, when the cow moved, as to prove to me that it had mistaken the object on which it had perched for something else. At other times, I have observed that the approach of the grey squirrel intimidated them, if one of these animals accidentally jumped on a branch close to them, although the $\mathrm{Owl}$ destroys a number of them during the twilight.

The Barred $\mathrm{Owl}$ is a great destroyer of poultry, particularly of chickens when half-grown. It also secures mice, young hares, rabbits, and many species of small birds, but is especially fond of a kind of frog of a brown colour, very common in the woods of Louisiana. I have heard it asserted that this bird catches fish, but never having seen it do so, and never having found any portion of fish in its stomach, I cannot vouch for the truth of the report.

About the middle of March, these Owls begin to lay their eggs. This they usually do in the hollows of trees, on the dust of the decomposed wood. At other times they take possession of the old nest of a Crow or a Red-tailed Hawk. In all these situations I have found their eggs and young. The eggs are of a globular form, pure white, with a smooth shell, and are from four to six in number. So far as I have been able to ascertain, they rear only one brood in a season. The young, like those of all other Owls, are at first covered with a downy substance, some of which is seen intermixed with and protruding from the feathers, some weeks after the bird is nearly fledged. They are fed by the parents for a long time, standing perched, and emitting a hissing noise in lieu of a call. This noise may be heard in a calm night, for fifty or probably a hundred yards, and is by no means musical. To a person lost in a swamp, it is, indeed, extremely dismal.

The plumage of the Barred Owl differs very considerably, in respect to colour, in different individuals, more especially among the males. The males are also smaller than the females, but less so than in some other species. During the severe winters of our Middle Districts, those that remain there suffer very much; but the greater number remove to the Southern States. When kept in captivity, they prove excellent mousers.

The antipathy shewn to Owls by every species of day bird is extreme. They are followed and pursued on all occasions; and although few of the 
day birds ever prove dangerous enemies, their conduct towards the 0 wls is evidently productive of great annoyance to them. When the Barred Owl is shot at and wounded, it snaps its bill sharply and frequently, raises all its feathers, looks towards the person in the most uncouth manner, but, on the least chance of escape, moves off in great leaps with considerable rapidity.

The Barred Owl is very often exposed for sale in the New Orleans market. The Creoles make gumbo of it, and pronounce the flesh palatable.

Barred Owl, Strix nebulosa, Wils. Amer. Orn., vol. iv. p. 61.

Strix nebulosa, Bonap. Syn., p. 38.

Barred Owl, Strix nebulosa, Nutt. Man., vol. i. p. 133.

Barred OwL, Strix nebulosa, Aud. Orn. Biog., vol. i. p. 242; vol. v. p. 386.

General colour of upper parts light reddish-brown; face and greater part of the head brownish-white; the feathers of the latter broadly marked with brown, of which a narrow band passes from the bill along the middle of the head; feathers of the back and most of the wing-coverts largely spotted with white; primary coverts, quills, and tail, barred with light brownish-red; wings and tail tipped with greyish-white; lower parts pale brownish-red, longitudinally streaked with brown, excepting the neck and upper part of the breast, which are transversely marked; the abdomen, which is yellowishwhite, and the tarsal feathers, which are light reddish.

Male, 18, 40.

\section{Genus V.-OTUS, Cuv. EARED-OWL.}

Bill short, stout, broader than high at the base, compressed toward the end; upper mandible with its dorsal line slightly curved from the base, toward the end decurved, the ridge broad at the base, narrowed anteriorly, the sides convex toward the tip, which is acute, and descends obliquely; lower mandible straight, with the dorsal line very short and slightly convex, the back and sides convex, the edges toward the end decurved, and with a slight sinus on each side, the tip obliquely truncate. Nostrils large, oblique, oblong. Conch of extreme size, extending from the level of the forehead over the eye to the chin in a semilunar form, with an anterior semicircular flap in its whole length; the aperture large, of a rhomboidal form. Feet of moderate length, and stout; tarsi short, feathered, as are the toes; the first shortest, the second and fourth nearly equal; claws long, curved in the fourth of a circle, extremely acute, the first and second rounded beneath. Plumage 
extremely soft and downy, facial disks complete, ruff distinct. Two small tufts of elongated feathers on the head. Wings long and broad; the second quill longest; the outer in its whole length, the second toward the end, and the first alular feather with the filaments disunited and recurved at the ends. Tail rather short, a little rounded.

\section{O N G - E A R E D OWL.}

† Otus vulgaris, Fleming.

PLATE XXXVII.-MALE.

This Owl is much more abundant in our Middle and Eastern Atlantic Districts than in the Southern or Western parts. My friend Dr. Bachman has never observed it in South Carolina; nor have I met with it in Louisiana, or any where on the Mississippi below the junction of the Ohio. It is not very rare in the upper parts of Indiana, Illinois, Ohio, and Kentucky, wherever the country is well wooded. In the Barrens of Kentucky its predilection for woods is rendered apparent by its not being found elsewhere than in the "Groves;" and it would seem that it very rarely extends its search for food beyond the skirts of those delightful retreats. In Pennsylvania, and elsewhere to the eastward, I have found it most numerous on or near the banks of our numerous clear mountain streams, where, during the day, it is not uncommon to see it perched on the top of a low bush or fir. At such times it stands with the body erect, but the tarsi bent and resting on a branch, as is the manner of almost all our Owls. The head then seems the largest part, the body being much more slender that it is usually represented. Now and then it raises itself and stands with its legs and neck extended, as if the better to mark the approach of an intruder. Its eyes, which were closed when it was first observed, are opened on the least noise, and it seems to squint at you in a most grotesque manner, although it is not difficult to approach very near it. It rarely on such occasions takes to wing, but throws itself into the thicket, and makes off on foot by means of pretty long leaps.

The Long-eared $\mathrm{Owl}_{\mathrm{w}}$ is careless as to the situation in which its young are to be reared, and generally accommodates itself with an abandoned nest of some other bird that proves of sufficient size, whether it be high or low, in the fissure of a rock or on the ground. Sometimes however it makes a nest itself, and this I found to be the case in one instance near the Juniata River in Pennsylvania, where it was composed of green twigs with the leaflets 


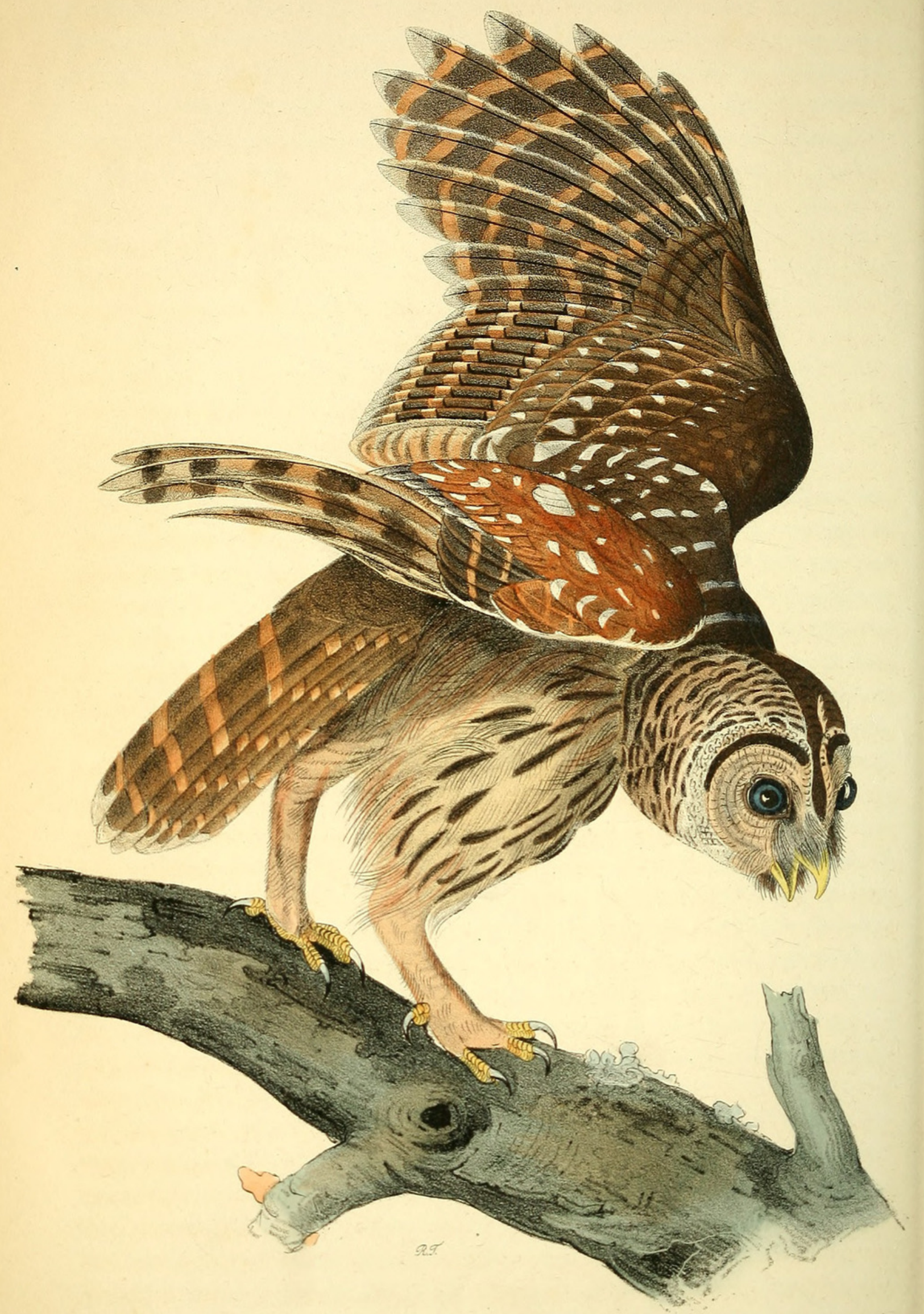




\section{$2 \mathrm{BHL}$ Biodiversity Heritage Library}

Audubon, John James. 1840. "The Barred Owl, Syrnium nebulosum, Linn. [PI. 36]." The birds of America: from drawings made in the United States and their territories 1, 132-136. https://doi.org/10.5962/p.319149.

View This Item Online: https://www.biodiversitylibrary.org/item/124833

DOI: https://doi.org/10.5962/p.319149

Permalink: https://www.biodiversitylibrary.org/partpdf/319149

\section{Holding Institution}

Smithsonian Libraries

\section{Sponsored by}

Biodiversity Heritage Library

\section{Copyright \& Reuse}

Copyright Status: NOT_IN_COPYRIGHT

This document was created from content at the Biodiversity Heritage Library, the world's largest open access digital library for biodiversity literature and archives. Visit BHL at https://www.biodiversitylibrary.org. 